\title{
Tobamovirus Coat Proteins: Elicitors of the Hypersensitive Response in Solanum melongena (Eggplant)
}

\author{
Christopher D. Dardick ${ }^{1}$ and James N. Culver ${ }^{1,2}$ \\ ${ }^{1}$ Molecular and Cell Biology Program, University of Maryland, College Park 20742, U.S.A.; and ${ }^{2}$ Center for \\ Agricultural Biotechnology, University of Maryland Biotechnology Institute, College Park 20742, U.S.A. \\ Received 13 March 1997. Accepted 6 May 1997.
}

\begin{abstract}
Solanum melongena (eggplant) exhibits a hypersensitive response (HR) when infected with tobacco mosaic tobamovirus (TMV). In contrast, a TMV mutant unable to express coat protein $(C P)$ did not elicit the $H R$, while a potexvirus vector engineered to express TMV CP did elicit the eggplant HR. The CPs of U2 and odontoglossum ringspot tobamoviruses also elicited the HR. However, the HR was not elicited by the $\mathrm{CP}$ of cucumber green mottle mosaic tobamovirus. Taken together, these findings demonstrate that specific tobamovirus CPs function as elicitors of the eggplant HR.
\end{abstract}

Additional keywords: resistance, virus.

Plants maintain sophisticated surveillance mechanisms that recognize and respond to specific pathogens. Recognition often leads to the induction of a cascade of host defense responses that result in localized cell death and disease resistance. This form of resistance, termed the hypersensitive response (HR), typically involves the interaction of specific pathogen avirulence genes ( $a v r$ ) with specific plant resistance genes $(R)$. Models for this gene-for-gene interaction predict that plant $R$ genes encode receptors that bind elicitors encoded by pathogen avr genes (Lamb et al. 1989; Gabrial and Rolfe 1990; Keen 1992). Molecular characterizations of both pathogen elicitors and plant $R$ genes have revealed a number of features suggestive of such a receptor-ligand interaction (Staskawicz et al. 1995; Bent 1996). In addition, direct evidence for a receptor-elicitor interaction has been demonstrated in at least one system (Scofield et al. 1996; Tang et al. 1996).

For tobamoviruses, several dominant or partially dominant plant $R$ genes conferring similar HRs have been genetically identified (Holmes 1938, 1946) and one $R$ gene, $N$ from Nicotiana glutinosa, has been molecularly cloned (Whitham et al. 1994). The viral determinants involved in eliciting some of these HRs have also been identified. They include the coat protein (CP), which elicits HRs conferred by the $N^{\prime}$ gene in $N$. sylvestris and the $L^{3}$ or $L^{2}$ genes in pepper (Culver and Dawson 1991; Berzal-Herranz et al. 1995; de la Cruz et al. 1997);

Corresponding author: J. N. Culver; Phone: (301) 405-2912; Fax: (301) 314-9075; E-mail: jc216@umail.umd.edu the 30-kDa cell-to-cell movement protein, which elicits HRs conferred by the $T m-2$ and $T m-2^{2}$ genes in tomato (Meshi et al. 1989; Weber et al. 1993); and the 126-kDa replicase protein, which elicits the HR conferred by the $N$ gene in $N$. glutinosa (Padgett and Beachy 1993). Host range studies also indicated the presence of additional tobamovirus-elicited HRs in other plant hosts (Holmes 1946). Thus, tobamoviruses provide an ideal system for comparing the mechanisms used by different hosts in pathogen recognition.

In this study, the ability of tobacco mosaic tobamovirus (TMV) to elicit necrotic local lesions in Solanum melongena (eggplant) was investigated (Holmes 1946). Eggplant leaves inoculated with TMV developed necrotic lesions at the sites of viral invasion within 2 to 3 days postinoculation (Fig. 1C). These lesions expanded slowly over time and were followed by abscission of the inoculated leaves within 2 to 3 weeks postinoculation. To determine whether the TMV CP was involved in eliciting this response, infectious RNA derived from a fulllength TMV cDNA construct missing the $\mathrm{CP}$ translational start codon (pTMVNS) (Culver 1996) was used to mechanically inoculate leaves of the eggplant cultivar Black Beauty (FerryMorse Seed Co., Fulton, KY). TMVNS has been shown to replicate and move from cell to cell at levels and rates comparable to those of wild-type TMV (Culver 1996; Culver and Dawson 1989). All plants were maintained in environmental growth chambers at $25^{\circ} \mathrm{C}$ under a 12 -h photoperiod and monitored for symptom development for a term of at least 3 weeks. To confirm the presence of TMVNS in infected tissues, Western immunoblots were conducted to detect the TMV 126$\mathrm{kDa}$ replicase protein (Fig. 2). Infected leaf tissue was pulverized directly in sample loading buffer and boiled for 5 min (Laemmli 1970). Sample proteins were resolved by sodium dodecyl sulfate-polyacrylamide gel electrophoresis and electrophoretically transferred to nitrocellulose paper. Transferred proteins were probed with either rabbit anti-126-kDa replicase antibodies or anti-CP antibodies (Lehto et al. 1990) followed by alkaline phosphatase-conjugated goat anti-rabbit antibody (Sigma, St. Louis, MO). Antibody-bound proteins were visualized by the addition of BCIP-NBT (5-bromo-4-chloro-3-indolylphosphate toluidinium-nitroblue tetrazolium) (Knecht and Dimond 1984). Results showed that TMVNS replicated in inoculated eggplant tissue but did not elicit the HR (Fig. 2). This 

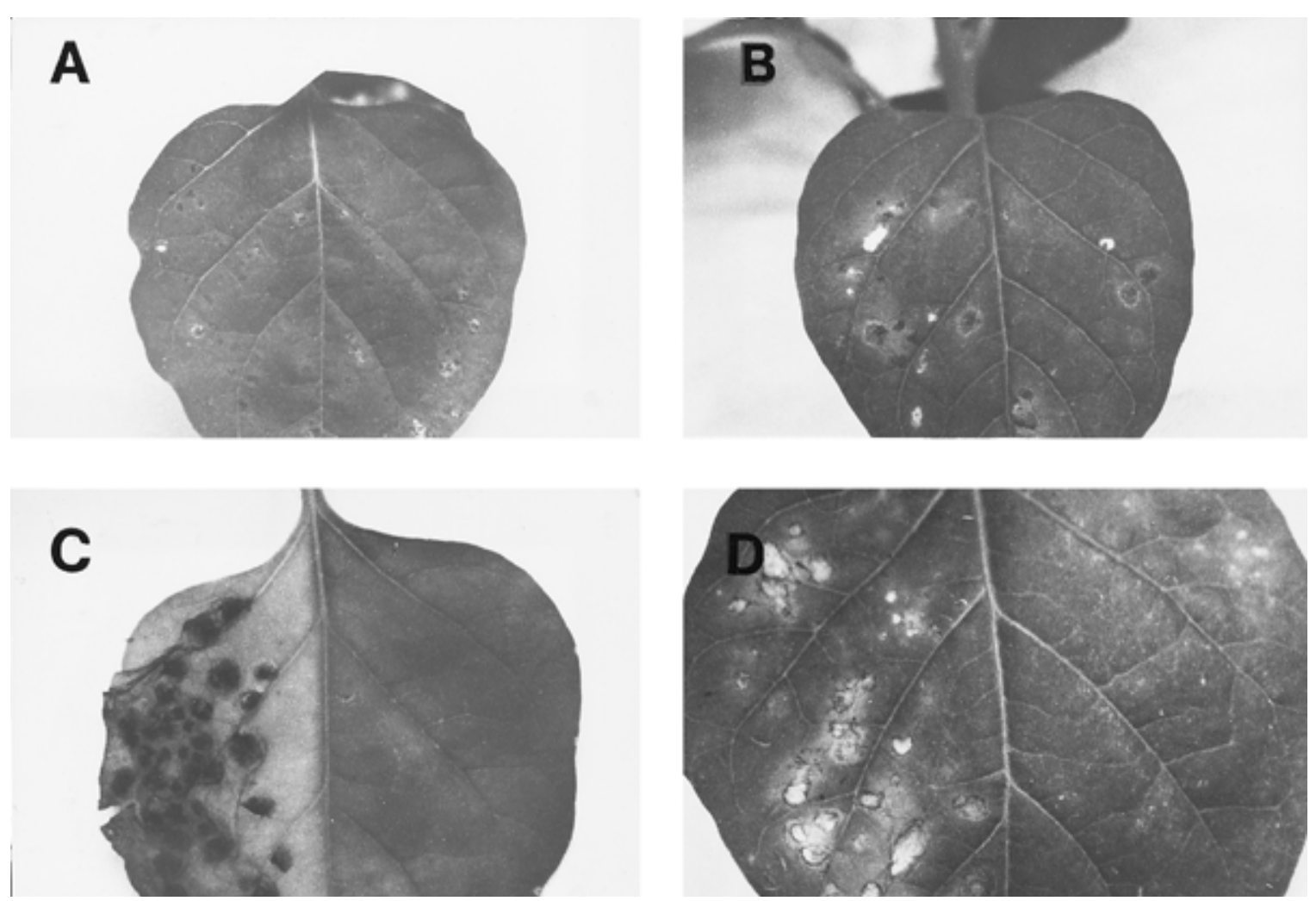

Fig. 1. Symptomatology of tobamovirus coat proteins (CPs) in eggplant. A, Tobacco mosaic tobamovirus (TMV) construct TMVCPU2 at 3 days postinoculation (dpi); B, TMVCPO (TMV construct expressing odontoglossum ringspot tobamovirus CP) at 6 dpi; C, TMVCPCGMMV (TMV construct expressing cucumber green mottle mosaic tobamovirus CP, right side) and wild-type TMV (left side) at 14 dpi; and D, potato X potexvirus (PVX) constructs PVX2C2S (right side) and PVXCP ${ }^{\mathrm{TMV}}$ (PVX expressing TMV CP, left side) at $14 \mathrm{dpi}$.

finding demonstrates a requirement for $\mathrm{CP}$ expression in the TMV elicitation of the eggplant HR.

To determine whether TMV CP functioned alone or in conjunction with other TMV components to elicit the eggplant $\mathrm{HR}$, a potato X potexvirus (PVX) vector, PVX2C2S (Chapman et al. 1992), was used to express the TMV CP. The TMV CP open reading frame was cloned into the unique EcoRV and SalI sites of pPVX2C2S to create pPVXCP ${ }^{\text {TMV }}$ (Culver 1996). Expression of the TMV CP in eggplant by $\mathrm{PVXCP}^{\mathrm{TMV}}$ was confirmed via Western immunoblot analysis (Fig. 3, lane 6). Eggplant leaves inoculated with $\mathrm{PVXCP}^{\mathrm{TMV}}$ developed necrotic lesions within 4 days, while leaves inoculated with the empty vector construct, PVX2C2S, displayed no visible symptoms (Fig. 1D). The local lesions elicited by $\mathrm{PVXCP}^{\mathrm{TMV}}$ generally appeared more slowly and were less defined than lesions elicited by TMV. This may be the result of differences in the levels and timing of $\mathrm{CP}$ expression between TMV and the PVX vector. The ability of PVXCP ${ }^{\mathrm{TMV}}$ but not of PVX2C2S to elicit the HR demonstrates that TMV CP expressed from a heterologous virus is sufficient to elicit the eggplant HR.

The HRs conferred by the tobacco $N^{\prime}$ gene and the pepper $L^{1}, L^{2}$, and $L^{3}$ genes are similarly elicited by CPs from a diverse group of tobamoviruses, including $\mathrm{U} 2$, odontoglossum ringspot (ORSV), and cucumber green mottle mosaic tobamoviruses (CGMMV) (Taraporewala and Culver 1997; C. D. Dardick, unpublished data). The ability of eggplant to recognize these different CPs was investigated by using TMV constructs containing substituted $\mathrm{CP}$ open reading frames from either U2 (TMVCP ${ }^{\mathrm{U} 2}$ ), ORSV (TMVCPO), or CGMMV

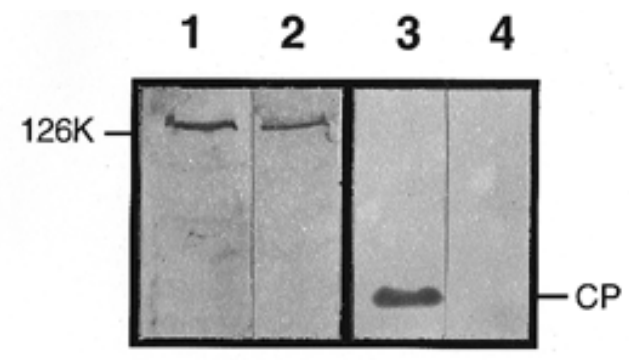

Fig. 2. Western immunoblot detection of tobacco mosaic tobamovirus (TMV) $126-\mathrm{kDa}$ protein and coat protein (CP) in tobacco tissue inoculated with TMV U1 (lanes 1 and 3) and eggplant tissue inoculated with TMVNS (lanes 2 and 4).

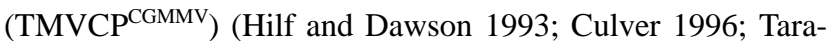
porewala and Culver 1997). CP expression in eggplant was monitored through Western immunoblot analysis (Fig. 3) (CGMMV antisera from the ATCC, Rockville, MD). CPs from U2 and ORSV were found to elicit an HR similar to the one elicited by the wild-type U1 CP (Fig. 1A and 1B). In contrast, the CP of CGMMV did not elicit the HR but instead induced spreading chlorosis within the inoculated leaf (Fig. 1C). It is interesting to note that the CP of CGMMV elicits the $N^{\prime}$ gene HR in tobacco, while the U1 CP does not elicit this response (Taraporewala and Culver 1997). This variation in the abilities of different CPs to act as elicitors in different hosts suggests that these plants target different $\mathrm{CP}$ features for recognition. 


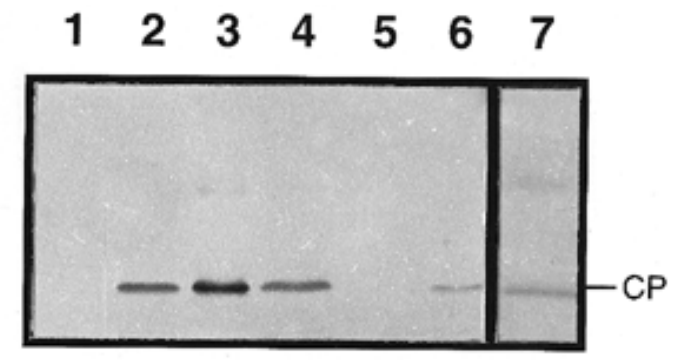

Fig. 3. Western immunoblot detection of coat protein $(\mathrm{CP})$ expression in inoculated eggplant tissue. Lane 1, healthy control; lane 2, tobacco mosaic tobamovirus (TMV) U1; lane 3, TMVCP ${ }^{\mathrm{U} 2}$ (TMV construct expressing U2 CP); lane 4, TMVCPO (TMV construct expressing odontoglossum ringspot tobamovirus $\mathrm{CP}$ ); lane 5 , potato $\mathrm{X}$ potexvirus (PVX) construct PVX2C2S; lane 6, PVXCPTMV (PVX expressing TMV CP); and lane 7, TMVCPCGMMV (TMV construct expressing cucumber green mottle mosaic tobamovirus $\mathrm{CP}$ ).

The structural features of the tobamovirus $\mathrm{CP}$ responsible for eggplant recognition remain unknown. However, features along the right face of the $\mathrm{CP}$ helical bundle, comprising a hydrophobic cavity and surrounding charged residues, were shown to be critical in the elicitation of the $N^{\prime}$ gene HR in $N$. sylvestris (Taraporewala and Culver 1996). Further analysis of the structural and biophysical features of $\mathrm{CP}$ involved in eliciting the eggplant HR and other host $R$ genes should result in a better understanding of the different mechanisms utilized by plants in pathogen recognition.

\section{ACKNOWLEDGMENTS}

We thank D. Baulcombe and W. O. Dawson for providing pPVX2C2S and pTMVCPO, respectively. This work was supported by NSF grant MCB 9506849 .

\section{LITERATURE CITED}

Bent, A. F. 1996. Plant disease resistance genes-Function meets structure. Plant Cell 8:1757-1771.

Berzal-Herranz, A., de la Cruz, A., Tenllado, F., Diaz-Ruiz, J. R., Lopez, L., Sanz, A. I., Vaquero, C., Serra, M. T., and Garcia-Luque, I. 1995. The Capsicum $L^{3}$ gene-mediated resistance against the tobamoviruses is elicited by the coat protein. Virology 209:498-505.

Chapman, S., Kavanagh, T., and Baulcombe, D. C. 1992. Potato virus X as a vector for gene expression in plants. Plant J. 2:549-557.

Culver, J. N. 1996. Tobamovirus cross protection using a potexvirus vector. Virology 226:228-235.

Culver, J. N., and Dawson, W. O. 1989. Tobacco mosaic virus coat protein: An elicitor of the hypersensitive reaction but not required for the development of systemic systems in Nicotiana sylvestris. Virology 173:755-758.
Culver, J. N., and Dawson, W. O. 1991. Tobacco mosaic virus elicitor coat protein genes produce a hypersensitive phenotype in transgenic Nicotiana sylvestris plants. Mol. Plant-Microbe Interact. 4:458-463.

de la Cruz, A., López, L., Tenllado, F., Díaz-Ruíz, J. R., Sanz, A. I., Vaquero, C., Serra, M. T., and García-Luque, I. 1997. The coat protein is required for the elicitation of the Capsicum $L^{2}$ gene-mediated resistance against the tobamoviruses. Mol. Plant-Microbe Interact. 10:107-113.

Gabriel, D. W., and Rolfe, B. G. 1990. Working models of specific recognition in plant-microbe interactions. Annu. Rev. Phytopathol. 28:365-391.

Hilf, M. E., and Dawson, W. O. 1993. The tobamovirus capsid protein functions as a host-specific determinant of long-distance movement. Virology 193:106-114.

Holmes, F. O. 1938. Inheritance of resistance to tobacco-mosaic disease in tobacco. Phytopathology 28:553-561.

Holmes, F. O. 1946. A comparison of the experimental host ranges of tobacco-etch and tobacco-mosaic viruses. Phytopathology 36:643-659.

Keen, N. T. 1992. The molecular biology of disease resistance. Plant Mol. Biol. 19:109-122.

Knecht, D., and Dimond, R. L. 1984. Visualization of antigenic proteins on Western blots. Anal. Biochem. 136:180-184.

Laemmli, U. K. 1970. Cleavage of structural proteins during the assembly of the head of bacteriophage T4. Nature 227:680-685.

Lamb, C. J., Lawton, M. A., Dron, M., and Dixon, R.A. 1989. Signals and transduction mechanisms for activation of plant defenses against microbial attack. Cell 56:215-224.

Lehto, K., Bubrick, P., and Dawson, W. O. 1990. Time course of TMV 30K protein accumulation in intact leaves. Virology 174:290-293.

Meshi, T., Motoyoshi, T., Maeda, T., Yoshiwoka, S., Watanabe, H., and Okada, Y. 1989. Mutations in the tobacco mosaic virus 30-kD protein gene overcome Tm-2 resistance in tomato. Plant Cell 1:515-522.

Padgett, H. S., and Beachy, R. N. 1993. Analysis of a tobacco mosaic virus strain capable of overcoming $N$ gene mediated resistance. Plant Cell 5:577-586.

Scofield, S. R., Tobias, C. M., Rathjen, J. P., Chang, J. H., Lavelle, D. T., Michelmore, R. W., and Staskawicz, B. J. 1996. Molecular basis of gene-for-gene specificity in bacterial speck disease of tomato. Science 274:2063-2065.

Staskawicz, B. J., Ausubul, F. M., Baker, B. J., Ellis, J. G., and Jones, J. D. G. 1995. Molecular genetics of plant disease resistance. Science 268:661-667.

Tang, X. Y., Frederick, R. D., Zhou, J. M., Halterman, D. A., Jia, Y. L., and Martin, G. B. 1996. Initiation of plant disease resistance by physical interaction of avrpto and pto kinase. Science 274:2060-2063.

Taraporewala, Z. F., and Culver, J. N. 1996. Identification of an elicitor active site within the three-dimensional structure of the tobacco mosaic virus coat protein. Plant Cell 8:169-178.

Taraporewala, Z. F., and Culver, J. N. 1997. Structural and functional conservation of the tobamovirus coat protein elicitor active site. Mol. Plant-Microbe Interact. 10:597-604.

Weber, H., Schultze, S., and Pfitzner, A. J. P. 1993. Two amino acid substitutions in the tomato mosaic virus 30-kilodalton movement protein counter the ability to overcome the $T m-2^{2}$ resistance gene in tomato. J. Virol. 67:6432-6438.

Whitham, S., Dinesh-Kumar, S. P., Choi, D., Hehl, R., Corr, C., and Baker, B. 1994. The product of the tobacco mosaic virus resistance gene $N$, similarity to Toll and interleukin-1 receptor. Cell 78:1101-1115. 